staje się uzasadnione, jeśli pamiętamy, że odbiorca podręcznika ma być białoruski student. Autor słusznie postrzega edukacje jako znaczqcy element całokształtu materialnego oraz duchowego dorobku ludzkości i w związku z tym w tekście widzimy czeste odniesienia do osiagnięć, w danym momencie dziejowym, wielkich Polaków w dziedzinach często odległych od edukacji (np. Kopernika). M. Dobrynin odnotowuje również tendencje rozwojowe występujące $w$ języku polskim $w$ poszczególnych epokach.

Niewątpliwym wzbogaceniem zasadniczego tekstu są liczne fragmenty źródel. Autor wyszedł tu zapewne ze słusznego założenia, że bialoruski czytelnik nie będzie miał możliwości samodzielnego dotarcia do cytowanych materiałów źródłowych.

Polskiego czytelnika pracy M. Dobrynina może dziwić fakt, iż włącza on odrodzenie w obręb średniowiecza, czyli prezentuje ujęcie charakterystyczne dla historiografii radzieckiej, według którego wieki średnie sięgają do rewolucji angielskiej w XVII w. Sądzę, że właściwsze byłoby potraktowanie renesansu jako epoki przejściowej między średniowieczem a czasami nowożytnymi czyli zgodnie z periodyzacją dziejów stosowana powszechnie $w$ Europie $\mathrm{Za}$ chodniej, a także w Polsce.

Należy żałować, że książka M. Dobrynina pozostawia wiele do życzenia pod względem edytorskim - liczne „literówki”, nie przystające do dzisiejszych możliwości drukarskich fotografie (których obecność, skądinąd, podnosi wartość pracy), mapka obrazująca poziom analfabetyzmu $w$ Polsce $w$ początkach lat 30-tych, nie wiadomo $z$ jakiego powodu, bez opisu w języku rosyjskim.

Reasumując, można stwierdzić, iż omawiana praca stanowi interesująca propozycję podręcznika historii wychowania dla studentów obcokrajowców.

Ewa Kuczyńska

\title{
Sonja Hander, Schülerkindheit in Ost-Berlin. Sozialisation unter den Bedingungen der Diktatur (1945-1958), Böhlau Verlag, Köln, Weimar, Wien 1998, ss. 383
}

U badaczy zachodnioniemieckich obserwuje się permanentny wzrost zainteresowań badawczych problemami życia w byłej NRD. Po otwarciu archiwów wschodnich zainteresowanie to uległo pogłębieniu. Ważną sferą badań jest szeroko pojęta edukacja $w$ totalitarnym państwie, jakim byla NRD.

W ten kontekst badań wpisuje się recenzowana książka. Autorka, jako socjolog interesujący się historią współczesną, pracuje na Politechnice Drezdeńskiej (Technische Universität) na Wydziale Nauk o Wychowaniu.

Na podstawie bogatych źródeł przedstawiła dzieciństwo uczniów w Berlinie Wschodnim w warunkach dyktatury w latach $1945-1958$. W 13-tu rozdziałach zaprezentowała etapy kształtowania się dyktatury socjalistycznej w NRD i jej odbicie w szkolnictwie i wychowaniu, które uznane były za jeden $\mathrm{z}$ najważniejszych odcinków frontu ideologicznego.
W rozdziale pierwszym (ss. 14-44) Autorka przedstawiła liczne pytania i wyjaśnienia związane ze stalinizacją szkolnictwa w sowieckiej strefie okupacyjnej, a od 1947 r. w NRD.

W latach 1945-1948 miały miejsce w tej części Niemiec poszukiwania demokratycznej reformy szkolnej. Zwiazane to było $z$ jednej strony $\mathrm{z}$ wpływem radzieckich władz okupacyjnych na wizje szkolnictwa $i$ angażowaniem do ich realizacji tzw. antyfaszystów niemieckich oraz faktem, że $71,6 \%$ nauczycieli, którzy przeżyli wojne, byli to członkowie NSDAP; sprzyjato zaś koncepcjom faszystowskim ok. $97 \%$. Powstał więc problem tzw. nowego nauczyciela (der neue „Volkslehrer”). Problemy te rozważał I Kongres Pedagogiczny w Berlinie w 1946 r. z udziałem 1000 nauczycieli, który przygotował podstawy niemieckiej reformy szkolnej, zapoczątkowanej w Berlinie (rozdz. II). 
W rezultacie rozpoczęła się systematyczna stalinizacja szkolnictwa w sowieckiej strefie okupacyjnej. Głównym inspiratorem była SED. Kolejne etapy stalinizacji państwa i szkolnictwa wyznaczały zjazdy SED i tzw. kongresy pedagogiczne, które stanowiły transmisję ustaleń partyjnych do nauczycieli, uczniów i rodziców. Problemy te przedstawia Autorka w rozdziale trzecim.

W kolejnych rozdziałach omówione jest wprowadzenie szkoły 10-letniej $\mathrm{z}$ nadzieją na wychowanie nowego człowieka, $\mathrm{z}$ naciskiem na młodzież robotniczo-chłopską- „Arbeiterkindgesellschaftlich tätig, politisch loyal" (s. 67) - to hasło przewodnic.

Druga konferencja SED w 1952 r, obradująca nad programem pracy partyjnej w szkolnictwie, nadała kierunek ideologiczny szkolnictwu i poleciła poszerzenie szeregów pionierów oraz FDJ jako organizacji masowych. „Schüler bereit zur Verteidigung der Heimat... in der Zeit des Aufbaus des Sozialismus" (s. 88 i 89). Rozpoczęła się też generalna laicyzacja i walka $\mathrm{z}$ Kościołem. To ogólnie treść piątego rozdziału.

W październiku 1953 r. odbyła się w tzw. Tschernyschewski-Haus w Halle konferencja pedagogiczna, która rozpoczęła tzw. nowy kurs (Neue Kurs in der Volksbildung). Rozpoczęła się walka o rodziców, którzy - jak skonstatowano - tkwili często jeszcze w tradycjach faszystowskich i burżuazyjnych. Nacisk położono na upartyjnienie rodziców, dyrektorów szkół, nauczycieli, przywódców ruchu pionierskiego itp. (rozdz. 6).

Po powrocie Waltera Ulbrichta i Otto Grotewohla z Moskwy z XX zjazdu KPZR rozpoczęła się $w$ szkolnictwie walka $z$ tzw. rewizjonizmem. Jest to treścią rozdziału siódmego.

Na tle przemian ogólnych Autorka przenosi czytelnika do Berlina, do lat $1945-1948 / 49$, by ukazać sytuację społeczną dzieci i młodzieży. W samym Berlinie było w tym czasie ponad 130 tys. dzieci bez opieki rodziców lub bez pełnej opieki rodzicielskiej, stwarzających olbrzymie problemy różnorodnej natury. Te kwestie przedstawia Autorka w rozdziale ósmym.
Rozdział 9 poświęcony jest ówczesnym rodzicom, warunkom mieszkaniowym w zburzonym w czasie ciężkich walk Berlinie i wychowaniu ulicznemu.

Von der 8. Volksschule zur sozialistischen Politechnischen Oberschule (1949-1958) to problematyka rozdziału 10-tego, w którym Autorka przedstawia rozwijanie pracy politycznej nad upodobnieniem szkolnictwa w Berlinie do wzorów radzieckich. Podkreśla się rolę, pozytywnie nastawionych do przemian ustrojowych, rodziców, a także wpływ samych dzieci na rodziców w kierunku przekształcania ich świadomości i kształtowania pozytywnego stosunku do postępujących przemian. Silne związki z tradycją chrześcijańską, zarówno ewangelicką jak i katolicką wpływały niewątpliwie na efekty wychowawcze $w$ wielu rodzinach, które posyłaty swe dzieci na katechizację oraz przygotowywały do Konfirmacji i I Komunii świętej.

W rozdziale 11 Autorka omawia rolę świąt i uroczystości internacjonalistycznych, partyjnych i państwowych w ksztaltowaniu postaw wychowawczych i powolnego, aczkolwiek systematycznego, zastępowania dotychczasowych tradycji uksztaltowanych przez rodzinę.

Dzień powszedni w szkole oraz perspektywy zawodu nauczycielskiego to problematyka rozdziału 12-tego. Dobrze oceniany nauczyciel musiał być tzw. "Multifunktionär". Obok pracy w szkole miał cały szereg obowiązków spolecznych i partyjnych.

Rozdział ostatni poświęcony jest niejako podsumowaniu, swoistemu bilansowi. Można zaryzykować twierdzenie, że w kwestii indoktrynacji politycznej w ustroju i szkolnictwie NRD istniało wiele elementów zbieżnych pomiędzy faszyzmem a stalinizmem.

Swą pracą Autorka poszerza i uszczegóławia efekty wielu innych badań. Wartość książki podnosi bogaty zestaw źródeł, znacznej liczby publikacji obcojęzycznych w zakresie literatury przedmiotu. Liczne i sugestywne sq ilustracje i tabele.

Książka stanowi nowe spojrzenie na problemy strategii $i$ taktyki w zakresie manipulacji spoleczeństwem przez edukację w ramach kształtowania się tzw. ustroju socjalistycznego.

Jan Hellwig 